\title{
Seasonal Variations in Physico-Chemical Properties of Yamuna Water and its Suitability for Irrigation
}

\author{
Rama Pal*, R.K. Dubey, S.K. Dubey and A.K. Singh \\ ICAR-Indian Institute of Soil and Water Conservation, Research Centre, \\ Chhalesar, Agra 282006 (Uttar Pradesh), India \\ *Corresponding author
}

\section{A B S T R A C T}

\section{Keywords \\ Bicarbonates, Boron, Nitrate, Sodium adsorption ratio (SAR), Residual sodium carbonate (RSC).}

\section{Article Info}

Accepted: 12 October 2017 Available Online: 10 December 2017
Indian urbanisation at fast pace has led to increased wastewater discharge into river Yamuna which is intensively used for irrigation in urban, peri-urban and rural areas. In this backdrop, water quality of Yamuna was assessed at six sites along a stretch from Mathura, Agra and Etawah during winters, summers, rainy and post-rainy seasons. The $\mathrm{pH}$ of Yamuna water (7.01-7.84) did not register conspicuous variations in different seasons and sites. Other physico-chemical parameters were maximum during summers (EC: $2.6-3 \mathrm{dS} / \mathrm{m}$, bicarbonate: $4.2-5.2 \mathrm{meq} \mathrm{l}^{-1}$, chloride: $7.0-8.6$ meq $\mathrm{l}^{-1}$, sodium adsorption ratio (SAR): $5.1-8.28$ and boron: $1.2-2.0 \mathrm{mg} \mathrm{l}^{-1}$ ). Nitrate was maximum (5.6 - $6.8 \mathrm{mgl}^{-1}$ ) during rainy season. Residual sodium carbonate (RSC) remained negative in all seasons and sites. Since, several physico-chemical parameters varied within slight to moderate restrictive use range, therefore, Yamuna water can be used for irrigation with certain recommended precautions.

\section{Introduction}

Water quality, a global concern, critically interlinks to sustainable agriculture, animal and human health and environmental quality worldwide including Indian subcontinent (Kumar et al., 2017). Indian rivers are getting polluted and contaminated on receiving the huge quantity of untreated wastewater being drained from urban and industrial sources (CPCB, 2012). Total wastewater generation from urban areas in India is above 38,000 MLD, out of which only $35 \%$ is treated (CPCB, 2010). Major Indian cities also extract freshwater from rivers for domestic and industrial usage, therefore, quality of river water stands critical from human and animal health as well as ecological point of view. Yamuna, a major tributary of river Ganges, originates from Yamunotri glacier $\left(38^{0} 59^{\prime} \mathrm{N} 78^{0} 27^{\prime} \mathrm{E}\right)$ in the lower Himalayas at an elevation of about $6387 \mathrm{~m}$ amsl. Yamuna has a catchment area of over $366,220 \mathrm{Km}^{2}$ and total length of about $1376 \mathrm{Km}$ (CPCB, 2012). Yamuna traverses seven states (Uttarakhand, Himachal Pradesh, Haryana, Delhi, Rajasthan, Uttar Pradesh and Madhya Pradesh) but its water is severely polluted in Delhi and Uttar Pradesh segments (Sharma et 
al., 2017). To abate the contamination and pollution of Yamuna, Government of India launched a mega project called Yamuna Action Plan in 1993 (CPCB, 2006), however, restoration of the ecological fitness of Yamuna water to the required water quality standards is yet a big concern. Farmers especially poor and marginal one lift Yamuna water and irrigate crops which can be detrimental to crop quality, soil, human and animal health and environmental quality (Hasan et al., 2017).

In this backdrop, a study covering about 410 $\mathrm{Km}$ stretch of Yamuna River was conducted during 2016 at six sites in three districts of Uttar Pradesh state (Mathura, Agra and Etawah) which is dominantly beset with sandy loam soils, semi-arid climate and annual rainfall of about $550-750 \mathrm{~mm}$. The already concluded studies on Yamuna water quality indicate that fitness of Yamuna water for irrigation of agricultural crops near Delhi is highly variable and unpredictable with respect to location within metropolitan limits and time (Sharma et al., 2017). Therefore, this study which involves a much large and less studied stretch of $410 \mathrm{Km}$ (Mathura to Etawah) was carried out to assess suitability of Yamuna water for irrigation to agricultural crops during winter, summer, rainy and postrainy seasons. This paper discusses the physico-chemical properties of Yamuna water vis-à-vis designate irrigation water quality guidelines to indicate its fitness for agricultural crops for advisory to the farmers.

\section{Materials and Methods}

\section{Sampling site}

A total of six sampling sites were selected along $410 \mathrm{Km}$ stretch of Yamuna River in three districts of Uttar Pradesh i.e., Mathura, Agra and Etawah (Figure 1). Two sites in each district (one $5 \mathrm{Km}$ upstream and another
$5 \mathrm{Km}$ downstream of first and last municipal drain, respectively) were sampled during each season i.e., winter, summer, rainy and postrainy seasons.

\section{Analysis of physico-chemical parameters}

Physico-chemical parameters viz., $\mathrm{pH}$, electrical conductivity (EC), ions concentration (boron, $\mathrm{Na}^{+}, \mathrm{Ca}^{2+}, \mathrm{Mg}^{2+}, \mathrm{HCO}_{3}{ }^{-}$ $\mathrm{CO}_{3}{ }^{2-}, \mathrm{Cl}$-and $\mathrm{NO}_{3}{ }^{2-}$ ) were estimated in Yamuna water, collected in pre-sterilised HDPE plastic bottles of $100 \mathrm{ml}$, following standard methods and procedures as per the APHA (2005). At every sampling site, three samples were collected i.e., from mid (D/2) of the river width (D) and one each at either side of river at D/4 transact from about one foot depth. These samples were composited and subjected to physico-chemical analysis. The physico-chemical parameters so determined were compared with the standard irrigation water quality guidelines given by Ayers and Westcot (1994) which has been presented in Table 1. Sodium toxicity hazard was assessed through determining SAR and RSC using following standard equations ( $1 \& 2$ ) furnished by Richards (1954) and Eaton (1950), respectively.

$$
\begin{aligned}
& * \mathrm{SAR}=\mathrm{Na}^{+} /\left[\left(\mathrm{Ca}^{2+}+\mathrm{Mg}^{2+}\right) / 2\right]^{1 / 2}(1) \\
& * * \mathrm{RSC}=\left(\mathrm{HCO}_{3}{ }^{-}+\mathrm{CO}_{3}{ }^{2-}\right)-\left(\mathrm{Ca}^{2+}+\mathrm{Mg}^{2+}\right) \\
& \text { (2) }\left(* \text { and } * *=\text { all concentrations are in meq } 1^{-1}\right)
\end{aligned}
$$

\section{Results and Discussion}

\section{pH and EC}

The $\mathrm{pH}$ of Yamuna water did not register any conspicuous variations at different sites and seasons (range: 7.01 to 7.84), however, it was most alkaline in summers (7.53 to 7.84 ), near neutral in rainy season (7.01 to 7.21) and moderate in post-rainy season (7.21 to 7.38 ) and winters (7.06 to 7.4) (Figure 2). The 
irrigation quality guidelines suggest that at this $\mathrm{pH}$ range, water can safely be used for all the crops and soil types. Earlier studies of Sharma et al., (2017) also well corroborate with these findings on river water $\mathrm{pH}$.EC of Yamuna water at different sites followed the order: summers (2.6 to $3 \mathrm{dS} / \mathrm{m})>$ post rainy season $(1.84$ to $2.45 \mathrm{dS} / \mathrm{m})>$ winters $(1.67$ to $2.34 \mathrm{dS} / \mathrm{m})>$ rainy season $(1.15$ to $1.50 \mathrm{dS} / \mathrm{m})$ (Figure 3). Higher EC during summer may be a cumulative effect of more solubility of ions at higher temperature, higher domestic wastewater discharge on account of more consumption of water, higher evaporation rate from surface of water bodies and lower flow rate of river. The lowest EC of Yamuna water during rainy season can be ascribed to high surface runoff and resultant dilution of dissolved ions that directly determine EC. It can be concluded that EC of Yamuna water at various sampling sites during different seasons was found to lie in slight to moderate range of restrictive use as per the irrigation water quality guidelines. These findings on EC of river water are supported by Islam et al., (2015) and Edopkayi et al., (2015). As such, care may be taken to not apply Yamuna water in excessive quantity on regular basis in agricultural crops since it may involve endanger of accumulation of salts in the crop root zone and build of adverse osmotic potential. Nevertheless, on sandy loam soils of study area Yamuna water can be used at moderate to optimum application levels with or without dilution and leaching of salts, which is also in accordance with Dastane (1969).

\section{Bicarbonate and chloride}

Bicarbonates become a concern at high $\mathrm{pH}$ (7.4 to 9.3), high ion concentration (>3 meq $\mathrm{1}^{-}$ ${ }^{1}$ ) and under drip or sprinkler methods of irrigation in view of deposition of lime on roots that causes iron induced chlorosis (Zuo et al., 2007). Data depict that bicarbonate concentration in Yamuna water i.e., summer (4.2 to $\left.5.2 \mathrm{meq}^{-1}\right)>$ post-rainy season $(2.2$ to $\left.3.8 \mathrm{meq}^{-1}\right)>$ winter $\left(2.1\right.$ to $\left.2.9 \mathrm{meq}^{-1}\right)>$ rainy season (1.0 to 2.0 meq $1^{-1}$ ) was found to be in slight to moderate restrictive range of water use for agricultural crops (Figure 4). Chloride concentration in Yamuna water followed an order i.e., summer (7.0 to $\left.8.6 \mathrm{meq}^{-1}\right)>$ postrainy season $\left(5.0\right.$ to $\left.6.0 \mathrm{meq}^{-1}\right)>$ winter ( 4.3 to $\left.5.0 \mathrm{meq}^{-1}\right)>$ rainy season $\left(1.5\right.$ to $\left.2 \mathrm{meq}^{-1}\right)$ (Figure 5). These results on bicarbonate and chloride in river water also corroborate with findings of Singh and Nath (2015). As such, except rainy season chloride concentration in Yamuna water was found to be fit for slight to moderate restrictive use for irrigation of agricultural crops in the zones of various sampling sites.

\section{SAR and RSC}

SAR, an indicator of mitigation of $\mathrm{Na}^{+}$hazard due to presence of $\mathrm{Ca}^{2+}$ and $\mathrm{Mg}^{2+}$ ions, was found to vary seasonally in order of summer (5.1to8.3)>post-rainy season (4.7 to 7.4)> winter (2.7 to 4.7$)>$ rainy season (2.6 to 4.3$)$, (Table 2). This shows that Yamuna water is safe from sodium toxicity hazard point of view as per the standard irrigation water quality guidelines. However, the values of SAR for Yamuna water are much higher than reported for other rivers by Thitame and Pondhe (2010), Maharana et al., (2015) and Hasan et al., (2017), which indicate huge flux of untreated domestic wastewater drained in Yamuna. Both, EC and SAR of irrigation water antagonistically affects water infiltration rate in soil. Therefore, EC and SAR of Yamuna water at different sites were correlated (Table 3), and it was found that from water infiltration hazard point of view Yamuna water can be used without any restrictions at all sites in different seasons except at $\mathrm{S}_{6}$ site during post-rainy season.

Table.1 Standard irrigation water quality guidelines (Ayers and Westcot, 1994) 


\begin{tabular}{|c|c|c|c|c|}
\hline \multirow{2}{*}{\multicolumn{2}{|c|}{ Parameter }} & \multicolumn{3}{|c|}{ Degree of Restriction on Use for irrigation } \\
\hline & & None & Slight to moderate & Severe \\
\hline \multicolumn{2}{|l|}{$\mathrm{pH}$} & \multicolumn{3}{|c|}{ Normal 6.5 to 8.4} \\
\hline \multicolumn{2}{|c|}{ Electrical conductivity (EC, dS/m) } & $<0.7$ & $0.7-3.0$ & $>3.0$ \\
\hline \multicolumn{2}{|c|}{ SAR } & $<3$ & 3. -9 & $>9$ \\
\hline $\mathrm{SAR}=0-3$ & $\mathrm{EC}=$ & $>0.7$ & $0.7-0.2$ & $<0.2$ \\
\hline$=3-6$ & & $>1.2$ & $1.2-0.3$ & $<0.3$ \\
\hline$=6-12$ & & $>1.9$ & $1.9-0.5$ & $<0.5$ \\
\hline$=12-20$ & & $>2.9$ & $2.9-1.3$ & $<1.3$ \\
\hline$=20-40$ & & $>5$ & $5-2.9$ & $<2.9$ \\
\hline \multicolumn{2}{|c|}{$\mathrm{RSC}$} & $<0$ & $0-2.5$ & $>2.5$ \\
\hline \multicolumn{2}{|c|}{ Bicarbonate (meq $1^{-1}$ ) } & $<1.5$ & $1.5-8.5$ & $>8.5$ \\
\hline \multicolumn{2}{|c|}{ Boron $\left(\mathrm{B}, \mathrm{mg} \mathrm{l}^{-1}\right)$} & $<0.7$ & $0.7-3.0$ & $>3.0$ \\
\hline \multicolumn{2}{|c|}{ Nitrate-N $\left(\mathrm{mg} \mathrm{l}^{-1}\right)$} & $<5.0$ & $5.0-30$ & $>30$ \\
\hline \multicolumn{2}{|c|}{ Chloride (meq $1^{-1}$ ) } & $<4$ & -10 & $>10$ \\
\hline
\end{tabular}

Table.2 Sodium adsorption ratio (SAR) of Yamuna water at different sampling sites in different seasons

\begin{tabular}{|c|c|c|c|c|}
\hline \multirow{2}{*}{$\begin{array}{c}\text { Sampling } \\
\text { sites }\end{array}$} & \multicolumn{4}{|c|}{ SAR } \\
\cline { 2 - 5 } & Winter & Summer & Rainy season & Post-rainy season \\
\hline $\mathrm{S}_{1}$ & 2.7 & 5.1 & 2.6 & 4.7 \\
\hline $\mathrm{S}_{2}$ & 3.6 & 5.4 & 3.1 & 5.8 \\
\hline $\mathrm{S}_{3}$ & 3.3 & 5.8 & 3.1 & 5.8 \\
\hline $\mathrm{S}_{4}$ & 3.6 & 6.8 & 3.6 & 6.4 \\
\hline $\mathrm{S}_{5}$ & 4.7 & 7.2 & 4.1 & 7.4 \\
\hline $\mathrm{S}_{6}$ & 4.5 & 8.3 & 4.3 & 7.3 \\
\hline
\end{tabular}

Table.3 Correlation of SAR and EC of Yamuna water at different sites for different seasons to 
assess degree of restriction for use in irrigation owing to infiltration hazard

\begin{tabular}{|c|c|c|c|}
\hline Sampling sites & SAR & $\mathrm{EC}$ & Degree of restriction for use in irrigation \\
\hline \multicolumn{4}{|l|}{ Winter } \\
\hline $\mathrm{S}_{1}$ & 2.7 & 2.05 & \multirow{6}{*}{ None } \\
\hline $\mathrm{S}_{2}$ & 3.6 & 2.15 & \\
\hline $\mathrm{S}_{3}$ & 3.3 & 2.07 & \\
\hline $\mathrm{S}_{4}$ & 3.6 & 2.34 & \\
\hline $\mathrm{S}_{5}$ & 4.7 & 1.86 & \\
\hline $\mathrm{S}_{6}$ & 4.5 & 1.67 & \\
\hline \multicolumn{4}{|l|}{ Summer } \\
\hline $\mathrm{S}_{1}$ & 5.1 & 3 & \multirow{6}{*}{ None } \\
\hline$S_{2}$ & 5.4 & 2.8 & \\
\hline $\mathrm{S}_{3}$ & 5.8 & 3 & \\
\hline $\mathrm{S}_{4}$ & 6.8 & 2.8 & \\
\hline $\mathrm{S}_{5}$ & 7.2 & 2.6 & \\
\hline $\mathrm{S}_{6}$ & 8.3 & 2.6 & \\
\hline \multicolumn{4}{|l|}{ Rainy season } \\
\hline $\mathrm{S}_{1}$ & 2.6 & 1.27 & \multirow{6}{*}{ None } \\
\hline $\mathrm{S}_{2}$ & 3.1 & 1.15 & \\
\hline $\mathrm{S}_{3}$ & 3.1 & 1.50 & \\
\hline $\mathrm{S}_{4}$ & 3.6 & 1.45 & \\
\hline $\mathrm{S}_{5}$ & 4.1 & 1.30 & \\
\hline $\mathrm{S}_{6}$ & 4.3 & 1.28 & \\
\hline \multicolumn{4}{|c|}{ Post-rainy season } \\
\hline $\mathrm{S}_{1}$ & 4.7 & 2.03 & \multirow{5}{*}{ None } \\
\hline $\mathrm{S}_{2}$ & 5.8 & 2.26 & \\
\hline $\mathrm{S}_{3}$ & 5.8 & 1.99 & \\
\hline $\mathrm{S}_{4}$ & 6.4 & 2.45 & \\
\hline $\mathrm{S}_{5}$ & 7.4 & 1.91 & \\
\hline $\mathrm{S}_{6}$ & 7.3 & 1.84 & Slight to moderate \\
\hline
\end{tabular}

Table.4 Residual sodium carbonate (RSC, meq $1^{-1}$ ) of Yamuna water at different sampling sites in different seasons

\begin{tabular}{|c|c|c|c|c|}
\hline \multirow{2}{*}{ Sampling sites } & \multicolumn{4}{|c|}{ RSC $\left(\mathrm{meq}^{-1}\right)$} \\
\cline { 2 - 5 } & Winter & Summer & Rainy season & Post-rainy season \\
\hline $\mathrm{S}_{1}$ & -1.5 & -4.0 & -0.4 & -2.2 \\
\hline $\mathrm{S}_{2}$ & -1.4 & -3.8 & -0.4 & -2.0 \\
\hline $\mathrm{S}_{3}$ & -1.0 & -3.4 & -1.9 & -2.8 \\
\hline $\mathrm{S}_{4}$ & -1.1 & -1.1 & -2.8 & -1.4 \\
\hline $\mathrm{S}_{5}$ & -0.8 & -0.9 & -1.8 & -0.9 \\
\hline $\mathrm{S}_{6}$ & -0.8 & -0.3 & -1.5 & -2.4 \\
\hline
\end{tabular}

Fig.1 Schematic representation of six sampling sites along Yamuna river, stretch from 


\section{Mathura to Etawah}

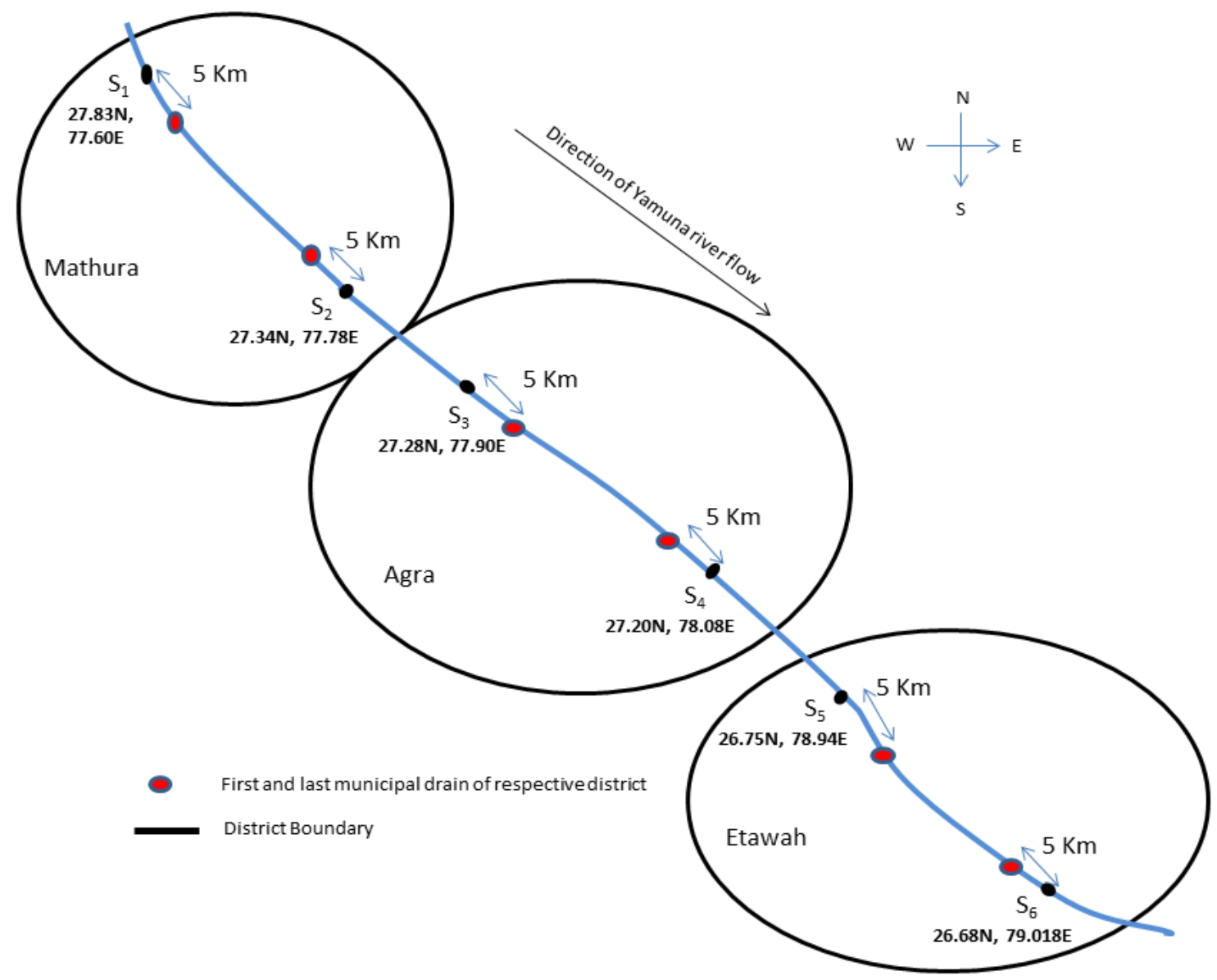

Fig.2 Seasonal variations in the $\mathrm{pH}$ of Yamuna water at different sampling sites

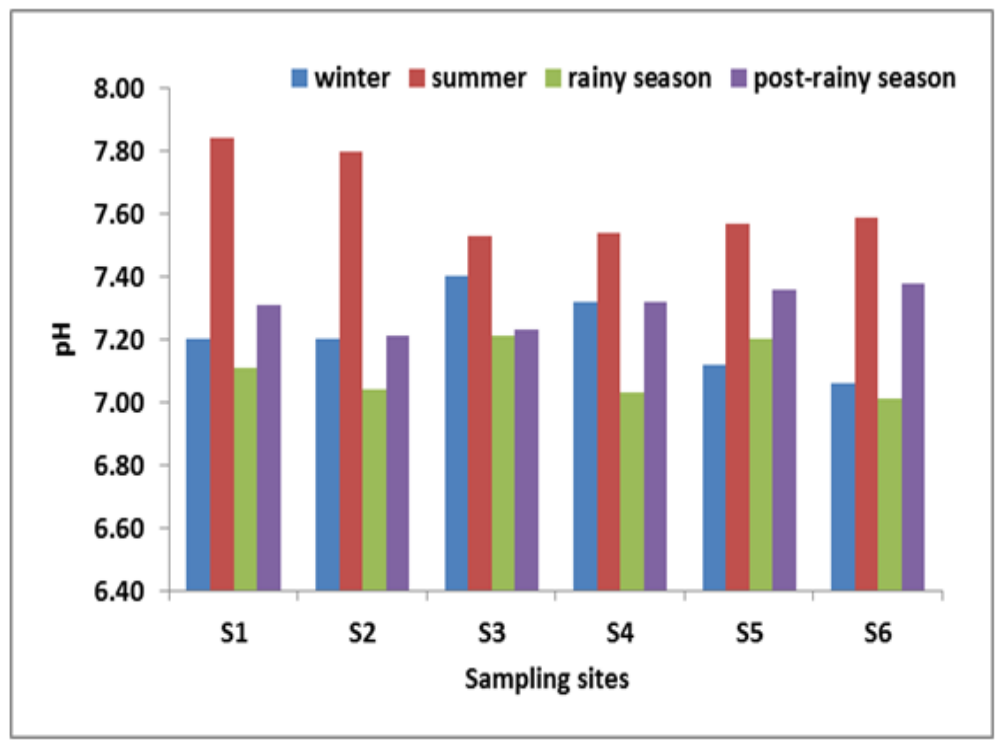

Fig.3 Seasonal variations in electrical conductivity (EC, dS/m) of Yamuna water at different 


\section{sampling sites}

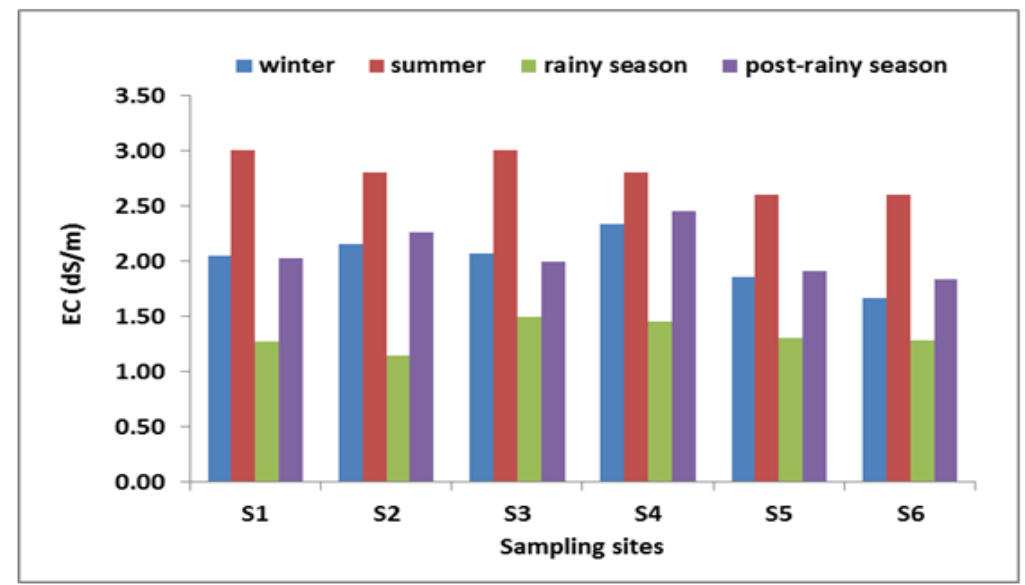

Fig.4 Seasonal variations in bicarbonate concentration $\left(\mathrm{meq}^{-1}\right)$ of Yamuna water at different sampling sites

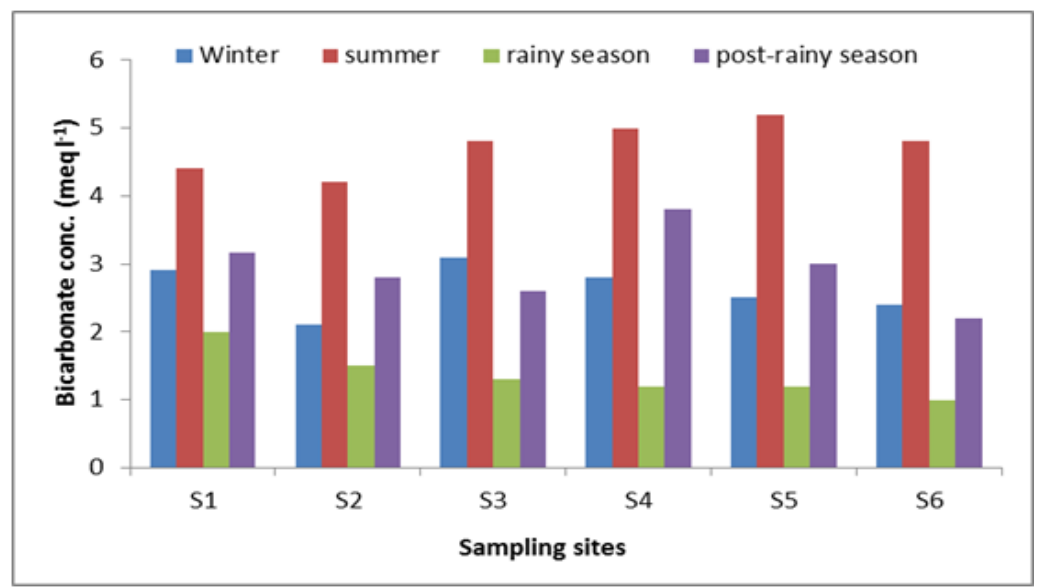

Fig.5 Seasonal variations in chloride concentration (meq $\mathrm{l}^{-1}$ ) of Yamuna water at different sampling sites

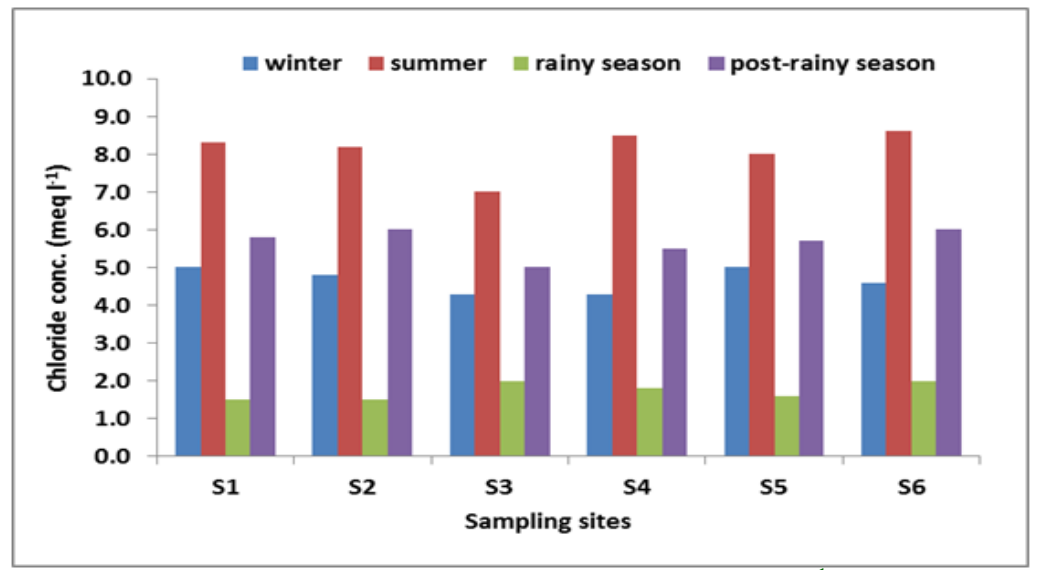

Fig.6 Seasonal variations in boron concentration $\left(\mathrm{mg}^{-1}\right)$ of Yamuna water 
at different sampling sites

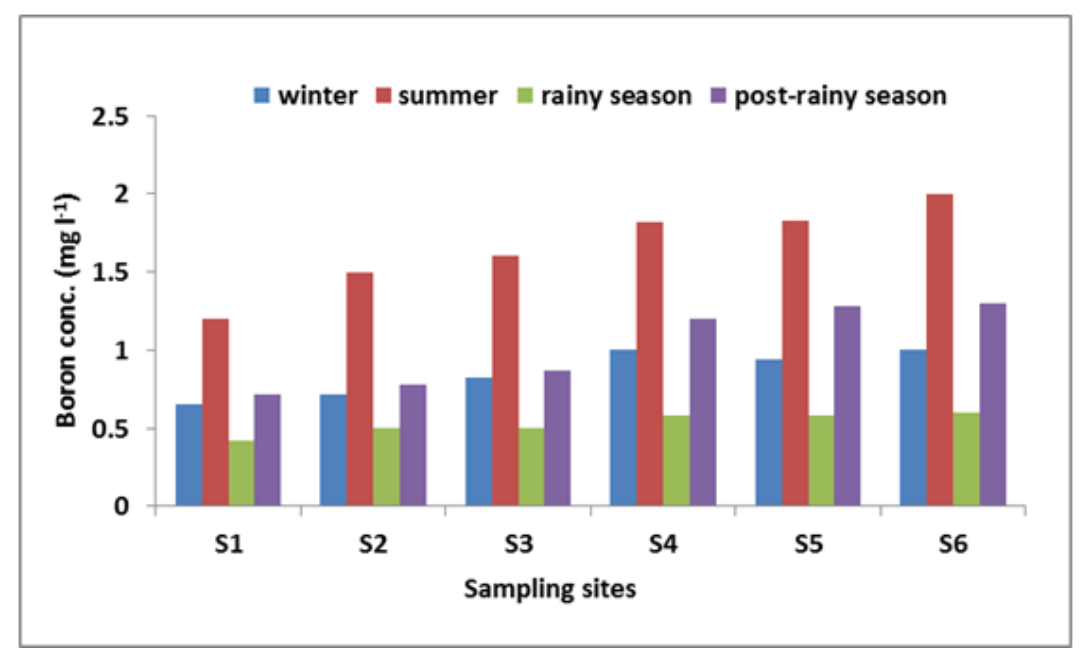

Fig.7 Seasonal variations in nitrate concentration $\left(\mathrm{mg}^{-1}\right)$ of Yamuna water at different sampling sites

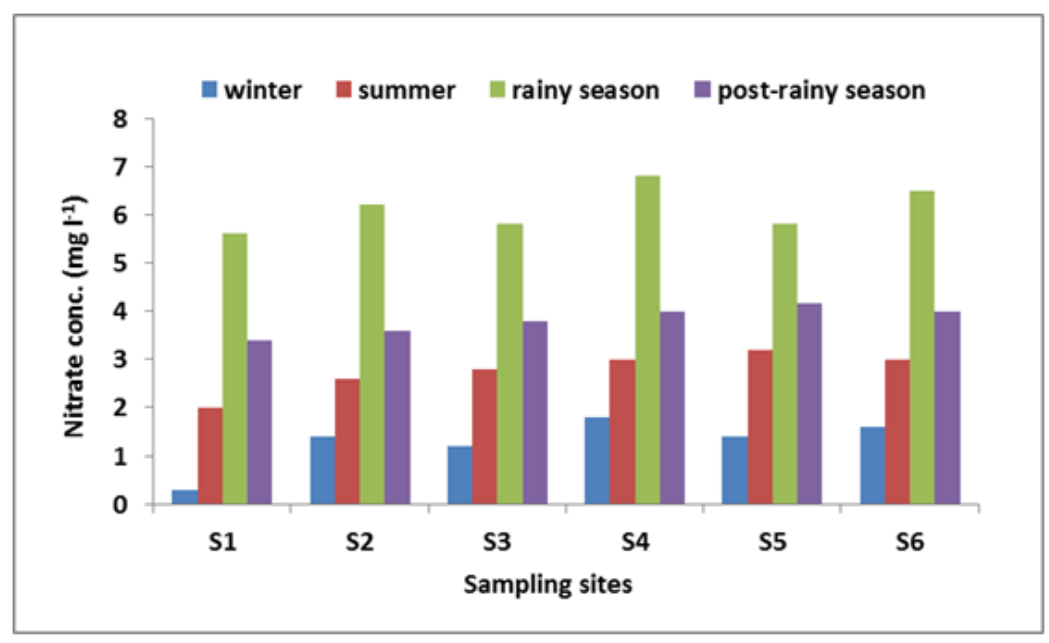

Since sodium hazard increases with increase in concentration of bicarbonate ions due to precipitation of $\mathrm{Ca}^{2+}$ and $\mathrm{Mg}^{2+}$ as carbonates, therefore, RSC becomes highly important in determining quality of irrigation water.

However, RSC of Yamuna water at various sampling sites in all seasons was negative and good for use in agriculture (Table 4).These results are also in conformity with the findings on RSC of river water by Haritash et al., (2016).

Boron
Boron, an essential element for crop plants becomes toxic above critical levels (Wimmer, 2013). Boron in river water can be contributed via cyclic seasalt, geothermal water, water-rock interaction i.e., chemical weathering and anthropogenic inputs (Liu et al., 2012). Boron in Yamuna water can involve action of last two sources i.e., chemical weathering and anthropogenic inputs. The concentration of boron in Yamuna water followed seasonal variations in order of summer (1.2 to $\left.2.0 \mathrm{mgl}^{-1}\right)>$ post-rainy season 
$\left(0.72\right.$ to $\left.1.3 \mathrm{mgl}^{-1}\right)>$ winter $\left(0.65\right.$ to $1.0 \mathrm{mgl}^{-}$ $\left.{ }^{1}\right)>$ rainy season $\left(0.42\right.$ to $\left.0.6 \mathrm{mgl}^{-1}\right)$, (Figure 6$)$. Boron concentration in Yamuna water falls under category of slight to moderate restrictive use. These results are also in conformity with findings of many authors working on water quality of Yamuna or other rivers in Indian subcontinent (Hassan et al., 2017).

\section{Nitrate}

Nitrate $\left(\mathrm{NO}_{3}{ }^{2-}\right)$ concentrations showed seasonal variations in order of rainy season (5.6 to $6.8 \mathrm{mgl}^{-1}$ )> post-rainy season (3.4to $\left.4.17 \mathrm{mgl}^{-1}\right)>$ summer $\left(2.0\right.$ to $\left.3.2 \mathrm{mgl}^{-1}\right)>$ winter $\left(0.3\right.$ to $\left.1.8 \mathrm{mgl}^{-1}\right)$ (Figure 7$)$. These values corresponds to nitrate-N (10 $\mathrm{mg} \mathrm{l}^{-1}$ nitrate- $\mathrm{N}=45 \mathrm{mg} \mathrm{l}^{-1}$ nitrate) as: rainy season $\left(1.23\right.$ to $\left.1.49 \mathrm{mgl}^{-1}\right)>$ post-rainy season $(0.748$ to $\left.0.92 \mathrm{mgl}^{-1}\right)>$ summer $\left(0.44\right.$ to $\left.0.70 \mathrm{mgl}^{-1}\right)>$ winter $\left(0.07\right.$ to $\left.0.39 \mathrm{mgl}^{-1}\right)$. In fact, higher concentration of nitrate in river water during rainy and post-rainy season over summers links to high runoff input from agricultural fields. As per the standard irrigation water quality guidelines, with existing nitrate-N level in Yamuna water, it can be used without any restrictions. Similar results on nitrate concentrations have also been reported by Sharma et al., (2017).

The results of this study showed that most of the physico-chemical parameters assessed for Yamuna water confirm to slight to moderate range of restrictive use for irrigation to agricultural crops. As such, a safer side practice i.e., desired dilution and judicious use of polluted/contaminated river water should be followed in long-term use of Yamuna water for irrigation of agricultural crops in the studied stretch for avoiding the adverse influences on human, animal and soil health as well as on environmental quality.

\section{References}

APHA 2005. Standard method for the estimation of water and waste water, 21st Ed., Washington DC

Ayers, R.S. and Westcot, D.W. 1994. Water quality for agriculture. Irrigation and Drainage Paper' 29 Rev. 1. FAO, Rome. 174p

CPCB, 2010. Status of water quality in India', Central Pollution Control Board, Ministry of Environment, Forest and Climate Change, Government of India.

CPCB, 2006. Water Quality Status of Yamuna River, Central Pollution Control Board, Ministry of Environment, Forest and Climate Change, Government of India.

CPCB, 2012. Status of water quality in India Central Pollution Control Board, Ministry of Environment, Forest and Climate Change, Government of India.

Dastane, N.G.1969. New concepts, practices and techniques in the field of water use and management. Proc ICAR Sym Water Management, Hisar, pp.109-133

Eaton, F.M. 1950. Significance of carbonates in irrigation waters. Soil Sci. Vol. 69, pp.123-133

Edokpayi, J.N.,Odiyo, J.O., Msagati Titus, A.M. and Potgieter, N. 2015.Temporal Variations in Physico-Chemical and Microbiological Characteristics of Mvudi River, South Africa. Int. J. Environ. Res. Public Health, Vol.12, No. 4, pp.4128-4140.

Haritash, A.K., Gaur, S. and Garg, S.2016.Assessment of water quality and suitability analysis of River Ganga in Rishikesh, India. Appl. Water Sci., Vol. 6, No.4, pp.383-392.

Hassan, T., Parveen, S., Bhat, BN. and Ahmad, U. 2017. Seasonal Variations in Water Quality Parameters of River Yamuna, India. Int. J. Curr. Microbiol. App. Sci., Vol.6, No. 5, pp.694-712.

Islam, M.S., Uddin, M.K., Tareq, S.M. et al., 2015. Alteration of Water Pollution 
Level with the Seasonal Changes in Mean Daily Discharge in Three Main Rivers around Dhaka City, Bangladesh. Environments, Vol. 2, pp.280-294.

Kumar,V., Sharma, A., Thukral, A.K. and Bhardwaj, R.2017. Water quality of River Beas, India. Current Sci., Vol.112, No.6, pp.1138-1157.

Liu, Y-C., You, C-F., Huang, K-F., Wang, RM., Chung, C-H. and Liu, H-C. 2012. Boron sources and transport mechanisms in river waters collected from southwestern Taiwan: Isotopic evidence.J. Asian Earth Sci., Vol. 58, pp.16-23.

Maharana, C., Gautam, S.K.,Singh, A.K. andTripathi, J.K.2015. Major ion chemistry of the Son River, India: Weathering processes, dissolved fluxes and water quality assessment. J. Earth Syst. Sci., Vol. 124, No. 6, pp.12931309.

Richards, L.A. 1954. Diagnosis and improvement of saline and alkali soils. United States Department of Agriculture, Washington, DC.

Sharma, S., Jha, P. K., Ranjan, M.R. et al., 2017. Water Quality Monitoring of
Yamuna River by Using GIS Based Water Quality Index in Delhi, India. Int. J. Curr. Microbiol. App. Sci., Vol. 6, No. 2, pp. 1249-1263.

Singh, S. and Nath, S. 2015. Water Quality Analysis of River Ganga and Yamuna during Mass Bathing, Allahabad, India.Uni. J. Environ. Res. Technol., Vol. 5, No.5, pp. 251-258.

Thitame, S.N. and Pondhe, G.M. 2010. Assessment of seasonal variation in physico-chemical characteristics and quality of Pravara River water for irrigation use in Sangamner, Dist Ahmednagar, Maharashtra. J. Chem. Pharm. Res., Vol. 2, No. 2, pp. 316-320.

Wimmer, M.A. and Eichert,T.2013.Review: mechanisms for boron deficiencymediated changes in plant water relations.Plant Sci., Vol. 203-204, pp.25-32

Zuo, Y., Ren, L., Zhang, F. and Jiang, R.F.2007. Bicarbonate concentration as affected by soil water content controls iron nutrition of peanut plants in a calcareous soil. Plant Physiol. Biochem., Vol. 45, No.5, pp.357-64.

\section{How to cite this article:}

Rama Pal, R.K. Dubey, S.K. Dubey and Singh, A.K. 2017. Seasonal Variations in PhysicoChemical Properties of Yamuna Water and its Suitability for Irrigation. Int.J.Curr.Microbiol.App.Sci. 6(12): 1638-1647. doi: https://doi.org/10.20546/ijcmas.2017.612.184 